\title{
A Preliminary Survey on Facilities Management Functions in Value Management Process in The Construction Stage
}

\author{
Nordiana Mohd Isa ${ }^{1}$, Syahrul Nizam Kamaruzzaman², Othman Mohamed ${ }^{3}$ \\ ${ }^{1,2}$ Department of Building Surveying, Faculty of Built Environment, University of Malaya, \\ 50603 Kuala Lumpur, Malaysia \\ ${ }^{3}$ Department of Quantity Surveying, Faculty of Built Environment, University of Malaya, \\ 50603 Kuala Lumpur, Malaysia
}

diana_isa@um.edu.my ${ }^{1 *}$,syahrulnizam@um.edu.my ${ }^{2}$,othmanmohamed@um.edu.my ${ }^{3}$

Received: 30 March 2018 Final Version Received: 28 August 2019

\begin{abstract}
Generally, Facilities Management (FM) managers play an important role in providing their input and knowledge of operation and maintenance in the process of Value Management (VM). Accordingly, an extensive literature review was conducted by the current research, followed by (Isa, Kamaruzzaman, Mohamed, \& Berawi, 2017) a preliminary survey that was aimed to confirm the FM functions obtained from the literature review phase. In the case of the present study, the preliminary survey or semi-structured interviews were carried out with a total of six experts due to their ability to confirm the factors. Meanwhile, descriptive statistics and content validity index (CVI) were adopted in the present study as the means of analysing the response data. In addition, a total of fifty items that belong to seven latent constructs managed to be developed from the literature review. More importantly, the results of the content validity analysis showed that the item-CVI values for six of the items were less than the cut-off value of 0.78 which was accompanied with a change of 50 to 44 items. Overall, it should be noted that the contribution of the current research is in the form of support to professionals and academicians which is believed to enhance their understanding on the importance of FM involvement in the VM process.
\end{abstract}

Keywords: Content Validity Index, Facilities Management, Functions, Malaysia, Preliminary Survey, Value Management

\section{INTRODUCTION}

Generally, the construction project involves several activities which are further categorised into three main stages, namely pre-construction, construction, and post-construction. Hence, the present study aims to conduct an in-depth investigation on the planning of construction projects with a particular focus on the preconstruction stage. According to Wood (2010), pre-construction can be clearly defined as "everything that takes place before the actual physical construction work on the site".

Regarding this matter, Nawi et al. (2014), Suhaimi (2014), and Tahir, Nawi, and Rajemi (2016) further suggest that VM can be used at any stage of project development. However, it has been widely used in the early stages of the construction project because it is able to offer the most benefits and may lead to a reduction of costs. A possible explanation for this may be due to the opportunities to make any changes considering that the cost of making such changes increases as the project progresses. Meanwhile, Hayles, Graham, and Fong (2010) pointed out that the VM application during pre-construction planning is able to reduce unnecessary costs without reducing the expected quality and performance at the early stage of a project, thus further attracting the interest of clients.

Traditionally, it is important to note that the project phase is segregated from the construction, operation, maintenance, and subsequent provision of services. In this case, Meng (2013) added that this segregation can lead to several issues in regard to the designed facilities which include the lack of constructability, operability, maintainability, and serviceability. Moreover, Ransley and Ingram (2001) postulated that the design tends to pose an effect on capital investment, efficiency, maintenance costs, sales, staffs, and profit. 
Nevertheless, the FM team appointed for a particular project is often being immediately rebuked for any potential design flaws. Therefore, it is important to manage FM requirements and conduct a prior checking amid design approval in order to enable an organisation to accomplish its objectives better after occupying a newly built facility.

On another note, Jawdeh (2013) discovered that FM managers are not aware of any FM participation during the pre-construction stage because it is not considered as a common practice. In addition, it has been assumed that FM and design are two separate entities which cause FM to be often overlooked during the preconstruction stage. More importantly, it should be noted that there will be no feedback on the proposed design elements without the involvement of the FM managers during the initial stage of the project. In this case, it is crucial to understand that these problems are unable to be detected in advance; hence, they are unlikely to be resolved in the pre-construction stage. Furthermore, this will cause the designed facilities to be more difficult and expensive to operate, maintain, and manage after the project is handed over. Therefore, a preliminary survey to identify and confirm a list of FM functions in the VM study during the pre-construction stage in the Malaysian context is deemed necessary to fill the existing gaps in the literature.

\subsection{Problem statement}

A considerable amount of scholars have highlighted the lack of early FM involvement during the pre-construction stage (Meng, 2013; Hassanain, Al-Hammad, \& Fatayer, 2014; Kalantari et al., 2017) considering that it is one of the major causes that lead to faulty design. In most cases, FM issues which include maintenance requirements in the design, access for maintenance equipment, and maintenance equipment availability and maintainability have not been significantly considered. Consequently, it is widely known that faulty design can significantly impact building maintenance which leads to the increase in maintenance budget, maintenance frequency and works, maintenance time and duration, and difficulty in maintenance policy and planning.

Furthermore, a number of studies revealed the importance of FM to be involved from the beginning of the project. In 2009, Jensen identified that a design review by FM managers is necessary before the final approval of the construction design. Moreover, this is supported by Femi (2014) who pointed out that the need for maintenance expert should not be overlooked in the planning stage of the project. However, far too little scholarly attention has been paid on the role of FM in the VM studies. Moreover, this is supported by El-Motasem in 2015 who stated that there is a lack of studies discussing the relationship of FM with VM in particular. Therefore, it is crucial for current research to investigate the importance of FM functions in VM studies.

\section{Literature Review}

\subsection{Fm Managers Role In Vm Studies During Pre-Construction Stage}

The findings from the literature review demonstrated the need to integrate FM through the role of the FM managers in VM studies (Isa et al., 2017). In this case, it should be noted that several important roles of FM managers during the pre-construction phase has been identified in the literature which involves the following factors: client satisfaction (ClientS), energy efficiency (EnerE), operation and maintenance (OpeM), space management (SpaceM), and sustainability (Sust).

\subsubsection{Client Satisfaction (ClientS)}

The term client can be broadly defined as a recipient of goods or services in return for monetary or other valuable considerations. Meanwhile, satisfaction can be loosely described as a feeling gained from the outcome of a process of evaluating what has been received against the expected, purchase decision itself and/or fulfilment of the needs. On a similar note, the term 'client satisfaction' is defined as the extent to which an FM service exceeds the expectation of the clients (Lepkova \& Jefimoviene, 2012). Furthermore, Feciková (2004) argued that client satisfaction is the main factor that determines how successful an organisation can be in maintaining customer relationships. Hence, it is important to measure the level of satisfaction within clients. Regarding this matter, it is deemed necessary for FM to be assessed at the pre-construction stage in order to understand how early involvement can create more efficient operations, increase value for money and client satisfaction as well as provide better facilities. In other words, an increasing number of satisfied customers can be achieved by understanding the information needs of clients and providing solutions that can be applied by them (Coenen \& Schäfer-Cui, 2013; Ikediashi, 2014). 


\subsubsection{Energy Efficiency (EnerE)}

Efficient energy consumption or also known as energy efficiency is meant to reduce the amount of energy required to provide products and services (Geethanjali, Hansa, \& Daniel, 2007). More importantly, this definition takes FM into account which becomes an important part of energy management due to the fact that energy costs are a part of the operating costs. Meanwhile, Tahir, Nawi, and Ibrahim (2016) described the main task of energy management which is to reduce the cost for energy provision in buildings and facilities without compromising the work processes. In other words, this clearly indicates that the service life and availability of equipment as well as the usage of facilities should remain the same. In this case, it is crucial to understand that all process involved in the project must be properly decided to ensure energy efficiency during its pre-construction phase. A clear explanation for this is that it will provide a significant effect on the overall construction project and most notably during the post-construction phase (operation and maintenance) (Cao, Song, \& Wang, 2015; Goulden \& Spence, 2015; PWD, 2017).

\subsubsection{Operation and Maintenance (OpeM)}

Sapp (2009) adopts the term operation and maintenance to refer to operation and maintenance of facilities that cover all aspects of the services necessary in order to ensure that the built environment is able to perform the functions of the facilities based on its design. Specifically, operation and maintenance involve the daily activities that are required for the systems as well as the equipment needed to perform the intended functions. In most cases, operations and maintenance tend to be combined as one and commonly known as O\&M considering that the facilities are unable to operate at maximum efficiency if it is not well maintained (Bascoul, 2017; Kalantari et al., 2017). Jawdeh (2013) pointed out that FM is faced with some operational issues which include access to a high level of lighting, chillers operation and maintenance, cleaning during occupancy, and coordination between floors due to the missing information about FM during the facilities design stage.

\subsubsection{Space Management (SpaceM)}

Space management is defined by Jackson (2015) as a physical space inventory of a company. Moreover, it should be understood that organisations require space management solutions for the purpose of automating the process of the facilities and ultimately reducing the costs of their occupancy. Consequently, they will be able to make the most out of their existing space which subsequently increases the overall productivity throughout their entire organisation. As stated by Wan-Hamdan, Hamid, and MohdRadzuan (2011), FM managers have a relatively important role in providing the information regarding the space needed during the preconstruction stage (Hassanain et al., 2014; Korpela et al., 2015).

\subsubsection{Sustainability (Sust)}

Generally, several definitions of sustainability have been proposed including the definition provided by IFMA (2017) which described sustainability as "a practice that will ensure the continued viability of a product or good practice into the future". However, the most commonly used definition comes from the 1983 United Nations Brundtland Commission that defines sustainability as a condition "which meets the needs of the present without compromising the ability of future generations to meet their own needs." Moreover, Hodges (2005) highlighted that FM managers are the key components in the development and operation of green buildings as well as the process of carrying out sustainable development. Therefore, this clearly indicates that FM managers have been recognised as appropriate professionals which further demonstrate FM value as a significant contributor to sustainable development (Nielsen, Sarasoja, \& Galamba, 2016; Oke \& Aigbavboa, 2017).

\subsection{Advantages of Fm Involvement in Vm Practice}

In a more general sense, FM is considered as a fuel for VM studies which further suggests that both of them should be applied in the early stages of projects considering that they are able to increase the value of the building. Apart from that, the involvement of FM adds a touch of sophistication in modern buildings apart from their ability to reduce the complexity, improve the design output, enhance the design efficiency, and minimise abortive work during construction and operation (Tladi, 2012; Enoma, 2005).

Regarding this matter, Jensen (2009) pointed out that the involvement of FM will ensure a smooth taking over of facilities which subsequently reduces future operational expenditure. Furthermore, Jensen (2009) and Jawdeh (2013) 
came to the conclusion that FM can generate proper FM requirements that will be able to fulfil the satisfaction of clients. In addition to these benefits, Tladi (2012) outlined several advantages of FM involvement considering that FM will be equipped with the knowledge about system preliminarily which allows better selection of equipment and materials. In this case, it is believed the advantages also include its potential to extend the accessibility to various equipment for maintenance and replacement (Kalantari et al., 2017). Other than that, FM involvement is also related to cost savings throughout the facility lifecycle (Tucker \& Masuri, 2016; Islam et al., 2017).

\subsection{Disadvantages of Non-Involvement of Fm in Vm Practice}

Regarding this matter, it is important to note a number of disadvantages that are caused by incorrect decisions made due to the absence of FM in VM studies. For instance, Rahman and Salim (2013) proposed access difficulties as one of the setbacks for maintenance purposes. Furthermore, Yasin (2013) and Meng (2013) draw our attention to the consequences of the inefficiency of the systems which include the wrong interpretation of designer that causes the failure of meeting FM requirements as well as the difficulties in cleaning, especially in external trade cleaning.

According to Ahzahar et al. (2011), FM managers should be aware of the possible consequences if FM involvement is being denied which include issues regarding electrical services and equipment, difficulties with deliveries and waste management, and failure to consider life cycle costing analysis. Likewise, Ishak et al. (2007) and Mustapa (2013) stated that the problems with fixtures as well as the fittings and troubles with the fabric of the buildings are also associated with the lack of FM involvement in VM studies.

\subsection{Latent Constructs of Fm Functions in Vm Studies}

The initial latent constructs that support the continuation of the current research to the following stage managed to be identified through the extensive literature review. Table 1 summarises the indicators for seven latent constructs and source references gathered from the literature review.

Table 1: Indicators for Latent Construct

\begin{tabular}{|c|c|c|c|}
\hline Latent Construct & Indicators & Description of Indicators & $\begin{array}{c}\text { Sources } \\
\end{array}$ \\
\hline \multirow[t]{7}{*}{$\begin{array}{l}\text { Client Satisfaction } \\
\quad \text { (ClientS) }\end{array}$} & ClientS1 & $\begin{array}{l}\text { Coordinate with clients to } \\
\text { ensure that all users and } \\
\text { owners requirements are } \\
\text { included in the brief. }\end{array}$ & $\begin{array}{l}\text { (Atkin \& Björk, 2007; Coenen \& } \\
\text { Schäfer-Cui, 2013; Ikediashi, } \\
\text { 2014; Jawdeh, 2013) }\end{array}$ \\
\hline & ClientS2 & $\begin{array}{l}\text { Assist in the preparation of the } \\
\text { project specifications. }\end{array}$ & $\begin{array}{l}\text { (Way, 2006; Toor \& Ogunlana, } \\
\text { 2010; Tladi, 2012; Lepkova \& } \\
\text { Uselis, 2013) }\end{array}$ \\
\hline & ClientS3 & $\begin{array}{l}\text { Answer questions prompted by } \\
\text { the designers. }\end{array}$ & $\begin{array}{l}\text { (Enoma, 2005; Shafie, Yusoff, \& } \\
\text { Pawi, 2012; Jawdeh, 2013) }\end{array}$ \\
\hline & ClientS4 & $\begin{array}{l}\text { Ensure the design of the } \\
\text { building is carried out to the } \\
\text { expectations of those who will } \\
\text { be utilising the facilities. }\end{array}$ & $\begin{array}{l}\text { (Yu, 2006; Noor \& Pitt, 2009; } \\
\text { Jawdeh, Wood, \& Abdul-Malak, } \\
\text { 2010; Ibiyemi \& Adnan, 2014) }\end{array}$ \\
\hline & ClientS5 & $\begin{array}{l}\text { Finalise the brief for clients to } \\
\text { sign off. }\end{array}$ & $\begin{array}{l}\text { (N. Lepkova \& Jefimoviene, } \\
\text { 2012; Jawdeh, 2013; Yasin, } \\
\text { 2013) }\end{array}$ \\
\hline & ClientS6 & $\begin{array}{l}\text { Provide post-occupancy } \\
\text { evaluation (POE) outcomes to } \\
\text { optimise building performance. }\end{array}$ & $\begin{array}{l}\text { (Preiser, 1995, 2003; Eley, 2001; } \\
\text { Ilesanmi, 2010; Koleoso, } \\
\text { Omirin, Adewunmi, \& } \\
\text { Babawale, 2013;) }\end{array}$ \\
\hline & ClientS7 & $\begin{array}{l}\text { Input on service level } \\
\text { agreements (SLA). }\end{array}$ & $\begin{array}{l}\text { (Feciková, 2004; Andersen, } \\
\text { 2006; Hui, Zhang, \& Zheng, } \\
\text { 2013) }\end{array}$ \\
\hline $\begin{array}{l}\text { Energy Efficiency } \\
\text { (EnerE) }\end{array}$ & EnerE1 & $\begin{array}{l}\text { Check the energy and resource } \\
\text { consumption. }\end{array}$ & $\begin{array}{l}\text { (Treloar, McCoubrie, Love, \& } \\
\text { Iyer-Raniga, 1999; Goulden \& } \\
\text { Spence, 2015; PWD, 2017) }\end{array}$ \\
\hline
\end{tabular}




\begin{tabular}{|c|c|c|c|}
\hline & EnerE2 & $\begin{array}{l}\text { Check the appropriateness of } \\
\text { energy saving. }\end{array}$ & $\begin{array}{l}\text { (Hajek, 2002; Liang, Li, Wu, \& } \\
\text { Yao, 2007; Xu, Chan, \& Qian, } \\
\text { 2011; Tahir, Nawi, \& Rajemi, } \\
\text { 2016) }\end{array}$ \\
\hline & EnerE3 & $\begin{array}{l}\text { Check the appropriateness of } \\
\text { utility services. }\end{array}$ & $\begin{array}{l}\text { (Cipriano, Carbonell, \& } \\
\text { Cipriano, 2009; Sheau, } \\
\text { Mohammed, Weng, \& Alias, } \\
\text { 2010; Dakwale, Ralegaonkar, \& } \\
\text { Mandavgane, 2011; Tahir, Nawi, } \\
\text { \& Ibrahim, 2016) }\end{array}$ \\
\hline & EnerE4 & $\begin{array}{l}\text { Check the appropriateness of } \\
\text { power and water consumption. }\end{array}$ & $\begin{array}{l}\text { (Geethanjali et al., 2007; Qian \& } \\
\text { Chan, 2010; Ng, 2013; Cao, } \\
\text { Song, \& Wang, 2015) }\end{array}$ \\
\hline & EnerE5 & Check the lighting aspects. & $\begin{array}{l}\text { ( Hartungi \& Jiang, 2012; Friege } \\
\& \text { Chappin, 2014; Goulden \& } \\
\text { Spence, 2015) }\end{array}$ \\
\hline \multirow[t]{8}{*}{$\begin{array}{l}\text { Operation and } \\
\text { Maintenance } \\
\text { (OpeM) }\end{array}$} & OpeM1 & $\begin{array}{l}\text { Provide technical information } \\
\text { to designers in producing the } \\
\text { best design. }\end{array}$ & $\begin{array}{l}\text { (Felten, Coenen, \& Arnold, } \\
\text { 2009; Fraser, 2014; Islam et al., } \\
\text { 2017) }\end{array}$ \\
\hline & OpeM2 & $\begin{array}{l}\text { Ensure that FM requirements } \\
\text { stated in the brief are actually } \\
\text { reflected in the concept design. }\end{array}$ & $\begin{array}{l}\text { (CIBSE, 2000; Meng, 2013b; } \\
\text { Kalantari et al., 2017) }\end{array}$ \\
\hline & OpeM3 & $\begin{array}{l}\text { Apply lifecycle costing in the } \\
\text { selection of materials and } \\
\text { equipment. }\end{array}$ & $\begin{array}{l}\text { (Zhang, 1999; Noor, 2014; } \\
\text { Pilanawithana \& Sandanayake, } \\
\text { 2017) }\end{array}$ \\
\hline & OpeM4 & $\begin{array}{l}\text { Ensure access in any area } \\
\text { inside the building for } \\
\text { maintenance work. }\end{array}$ & $\begin{array}{l}\text { ( Chotipanich, 2004; Tladi, 2012; } \\
\text { Bascoul, 2017) }\end{array}$ \\
\hline & OpeM5 & $\begin{array}{l}\text { Raise the O\&M issues to avoid } \\
\text { defects during occupancy. }\end{array}$ & $\begin{array}{l}\text { (Jaunzens et al., 2001; Sapp, } \\
\text { 2009; Tucker \& Masuri, 2016) }\end{array}$ \\
\hline & OpeM6 & $\begin{array}{l}\text { Assist in managing the } \\
\text { selection of the materials and } \\
\text { equipment to avoid operational } \\
\text { issues. }\end{array}$ & $\begin{array}{l}\text { (De Silva, 2011; Mustapa, 2013; } \\
\text { Poór, Kuchtová, \& Šimon, 2014) }\end{array}$ \\
\hline & OpeM7 & $\begin{array}{l}\text { Check the permanently fixed } \\
\text { elements in areas that require } \\
\text { continuous maintenance works. }\end{array}$ & $\begin{array}{l}\text { (Aris, 2006; Jawdeh, 2013; } \\
\text { Potkany, Vetrakova, } \\
\text { Babiakova, 2015) }\end{array}$ \\
\hline & OpeM8 & $\begin{array}{l}\text { Check the ease of cleaning and } \\
\text { maintaining the building and } \\
\text { surrounding areas. }\end{array}$ & $\begin{array}{l}\text { Enoma, 2005; Tladi, 2012; } \\
\text { Hassanain, Al-Hammad, \& } \\
\text { Fatayer, 2014) }\end{array}$ \\
\hline \multirow[t]{5}{*}{$\begin{array}{l}\text { Space Management } \\
\text { (SpaceM) }\end{array}$} & SpaceM1 & $\begin{array}{l}\text { Ensure the design emphasises } \\
\text { on the efficient and effective } \\
\text { space use. }\end{array}$ & $\begin{array}{l}\text { (Che Mat \& Shah, 2006; Lavy, } \\
\text { 2013; Jensen et al., 2014) }\end{array}$ \\
\hline & SpaceM2 & Ensure a high rate of utilisation. & $\begin{array}{l}\text { (Che Mat \& Shah, 2006; De } \\
\text { Silva, 2011; Wang et al., 2013; } \\
\text { Abdullah et al., 2014) }\end{array}$ \\
\hline & SpaceM3 & $\begin{array}{l}\text { Provide info on Computerised } \\
\text { Maintenance Management } \\
\text { System (CMMS). }\end{array}$ & $\begin{array}{l}\text { (Zakaria et al., 2010; Shen, Hao, } \\
\& \text { Xue, 2012; Hungu, 2013) }\end{array}$ \\
\hline & SpaceM4 & $\begin{array}{l}\text { Provide information on space } \\
\text { needs. }\end{array}$ & $\begin{array}{l}\text { (Ibrahim, Yusoff, \& Sidi, 2011; } \\
\text { Jawdeh, 2013; Korpela et al., } \\
\text { 2015) }\end{array}$ \\
\hline & SpaceM5 & $\begin{array}{l}\text { Assist general layout and } \\
\text { circulation. }\end{array}$ & $\begin{array}{l}\text { (Yu, 2006; Becerik-Gerber et al., } \\
\text { 2012; Hassanain et al., 2014) }\end{array}$ \\
\hline $\begin{array}{l}\text { Sustainability } \\
\quad \text { (Sust) }\end{array}$ & Sust1 & $\begin{array}{l}\text { Check the appropriateness of } \\
\text { sustainability aspects. }\end{array}$ & $\begin{array}{l}\text { (Hodges, 2005; Elmualim, Valle, } \\
\& \quad \text { Kwawu, 2012; Nielsen, } \\
\text { Sarasoja, \& Galamba, 2016) }\end{array}$ \\
\hline
\end{tabular}




\begin{tabular}{|c|c|c|c|}
\hline & Sust2 & $\begin{array}{l}\text { Provide input for the waste } \\
\text { disposal system. }\end{array}$ & $\begin{array}{l}\text { (Bosch \& Pearce, } 2003 \text {; Lee \& } \\
\text { Kang, 2013; } \\
\text { Rathnayake, \& } \\
\text { 2016) }\end{array}$ \\
\hline & Sust3 & $\begin{array}{l}\text { Ensure that the design takes } \\
\text { into account sustainability } \\
\text { considerations. }\end{array}$ & $\begin{array}{l}\text { (Elmualim et al., 2010; Price, } \\
\text { Pitt, \& Tucker, 2011; Oke \& } \\
\text { Aigbavboa, 2017) }\end{array}$ \\
\hline & Sust4 & $\begin{array}{l}\text { Avoid the designing of non- } \\
\text { environmentally } \\
\text { systems. }\end{array}$ & $\begin{array}{l}\text { (Savanick, Strong, \& Manning, } \\
\text { 2008; Saleh et al., 2011; Wright } \\
\text { \& Wilton, 2012; Chan, 2014) }\end{array}$ \\
\hline & Sust5 & $\begin{array}{l}\text { Provide a reference for the } \\
\text { selection of options for new } \\
\text { products introduced and } \\
\text { discuss their suitability. }\end{array}$ & $\begin{array}{l}\text { (Hayles, Graham, \& Fong, 2010; } \\
\text { Price, 2012; Jawdeh, 2013) }\end{array}$ \\
\hline \multirow[t]{10}{*}{ Advantages (Adv) } & Adv1 & $\begin{array}{l}\text { Proper addressing of client and } \\
\text { FM requirements to achieve } \\
\text { satisfaction. }\end{array}$ & $\begin{array}{l}\text { (Jawdeh, 2013; Islam et al., } \\
\text { 2017) }\end{array}$ \\
\hline & Adv2 & $\begin{array}{l}\text { Address sophistication in } \\
\text { modern buildings and reducing } \\
\text { complexity. }\end{array}$ & $\begin{array}{l}\text { (Jaunzens et al., 2001; Bascoul, } \\
\text { 2017) }\end{array}$ \\
\hline & Adv3 & $\begin{array}{l}\text { Improve the design output and } \\
\text { increase design efficiency. }\end{array}$ & $\begin{array}{l}\text { (Arditi \& Nawakorawit, 1999; } \\
\text { Kalantari et al., 2017) }\end{array}$ \\
\hline & Adv4 & $\begin{array}{l}\text { Minimise abortive work during } \\
\text { construction and operation. }\end{array}$ & $\begin{array}{l}\text { (Enoma, 2005; Tucker \& Masuri, } \\
\text { 2016) }\end{array}$ \\
\hline & Adv5 & $\begin{array}{lrr}\begin{array}{l}\text { Achieve } \\
\text { throughout }\end{array} & \text { cost } & \text { savings } \\
\text { lifecycle. } & \text { the } & \text { facilities } \\
\end{array}$ & $\begin{array}{l}\text { (Jawdeh, 2013; Pilanawithana \& } \\
\text { Sandanayake, 2017) }\end{array}$ \\
\hline & Adv6 & $\begin{array}{l}\text { Ensure a smooth taking over of } \\
\text { facilities. }\end{array}$ & (Aris, 2006; Potkany et al., 2015) \\
\hline & Adv7 & $\begin{array}{llr}\text { Increase accessibility to } & \text { to } \\
\text { various equipment for } \\
\text { maintenance and replacements. }\end{array}$ & $\begin{array}{l}\text { (Jawdeh, 2013; Von Felten et al., } \\
\text { 2009) }\end{array}$ \\
\hline & Adv8 & $\begin{array}{l}\text { FM provides knowledge about } \\
\text { the systems early on. }\end{array}$ & $\begin{array}{l}\text { (De Silva, 2011; Mcauley et al., } \\
\text { 2015) }\end{array}$ \\
\hline & Adv9 & $\begin{array}{l}\text { Better selection of equipment } \\
\text { and materials. }\end{array}$ & $\begin{array}{l}\text { (Tladi, 2012; Hassanain et al., } \\
\text { 2014) }\end{array}$ \\
\hline & Adv10 & $\begin{array}{ll}\text { Reduce future operational } \\
\text { expenditure. }\end{array}$ & $\begin{array}{l}\text { (Jawdeh et al., 2010; Meng, } \\
\text { 2013) }\end{array}$ \\
\hline \multirow[t]{9}{*}{$\begin{array}{l}\text { Disadvantages } \\
\text { (DisAdv) }\end{array}$} & DisAdv1 & $\begin{array}{llr}\begin{array}{l}\text { Designer's } \\
\text { interpretation } \\
\text { requirements. }\end{array} \text { of } & \text { Frong } \\
\end{array}$ & $\begin{array}{l}\text { (Femi, 2014; Tucker \& Masuri, } \\
\text { 2016) }\end{array}$ \\
\hline & DisAdv2 & Systems inefficiency. & $\begin{array}{l}\text { (Alriwaimi \& Akasah, 2014; } \\
\text { Pilanawithana \& Sandanayake, } \\
\text { 2017) }\end{array}$ \\
\hline & DisAdv3 & Clients' loss of profit. & $\begin{array}{l}\text { (Suffian, 2013; Kalantari et al., } \\
\text { 2017) }\end{array}$ \\
\hline & DisAdv4 & $\begin{array}{lcc}\text { Access difficulties } & \text { for } \\
\text { maintenance purposes. } & \\
\end{array}$ & $\begin{array}{l}\text { (Rahman \& Salim, 2013; Yasin, } \\
\text { 2013) }\end{array}$ \\
\hline & DisAdv5 & Cleaning difficulties. & (Jensen, 2009; Jawdeh, 2013) \\
\hline & DisAdv6 & $\begin{array}{l}\text { Failure to consider lifecycle } \\
\text { costing analysis. }\end{array}$ & $\begin{array}{l}\text { (Razak \& Jaafar, 2012; El- } \\
\text { Motasem, 2015) }\end{array}$ \\
\hline & DisAdv7 & $\begin{array}{l}\text { Problems with electrical } \\
\text { services and equipment. }\end{array}$ & $\begin{array}{l}\text { (Ahzahar et al., 2011; Tladi, } \\
\text { 2012) }\end{array}$ \\
\hline & DisAdv8 & $\begin{array}{l}\text { Problems with fixtures and } \\
\text { fittings. }\end{array}$ & $\begin{array}{l}\text { (Ishak, et al., 2007; Mustapa, } \\
\text { 2013) }\end{array}$ \\
\hline & DisAdv9 & $\begin{array}{l}\text { Problems with the building } \\
\text { fabric. }\end{array}$ & $\begin{array}{l}\text { (Al-Hammad, Assaf, \& Al- } \\
\text { Shihah, 1997; De Silva, 2011) }\end{array}$ \\
\hline
\end{tabular}




\begin{tabular}{|l|c|l|l|}
\hline & DisAdv10 & $\begin{array}{l}\text { Problems with deliveries and } \\
\text { waste management. }\end{array}$ & (Pitt, 2005; Potkany et al., 2015) \\
\hline
\end{tabular}

\subsection{The Conceptual Framework of Fm Functions in Vm Study}

The indicators identified from the literature review managed to provide the theoretical in developing the conceptual framework for the present study as shown in Figure 1.

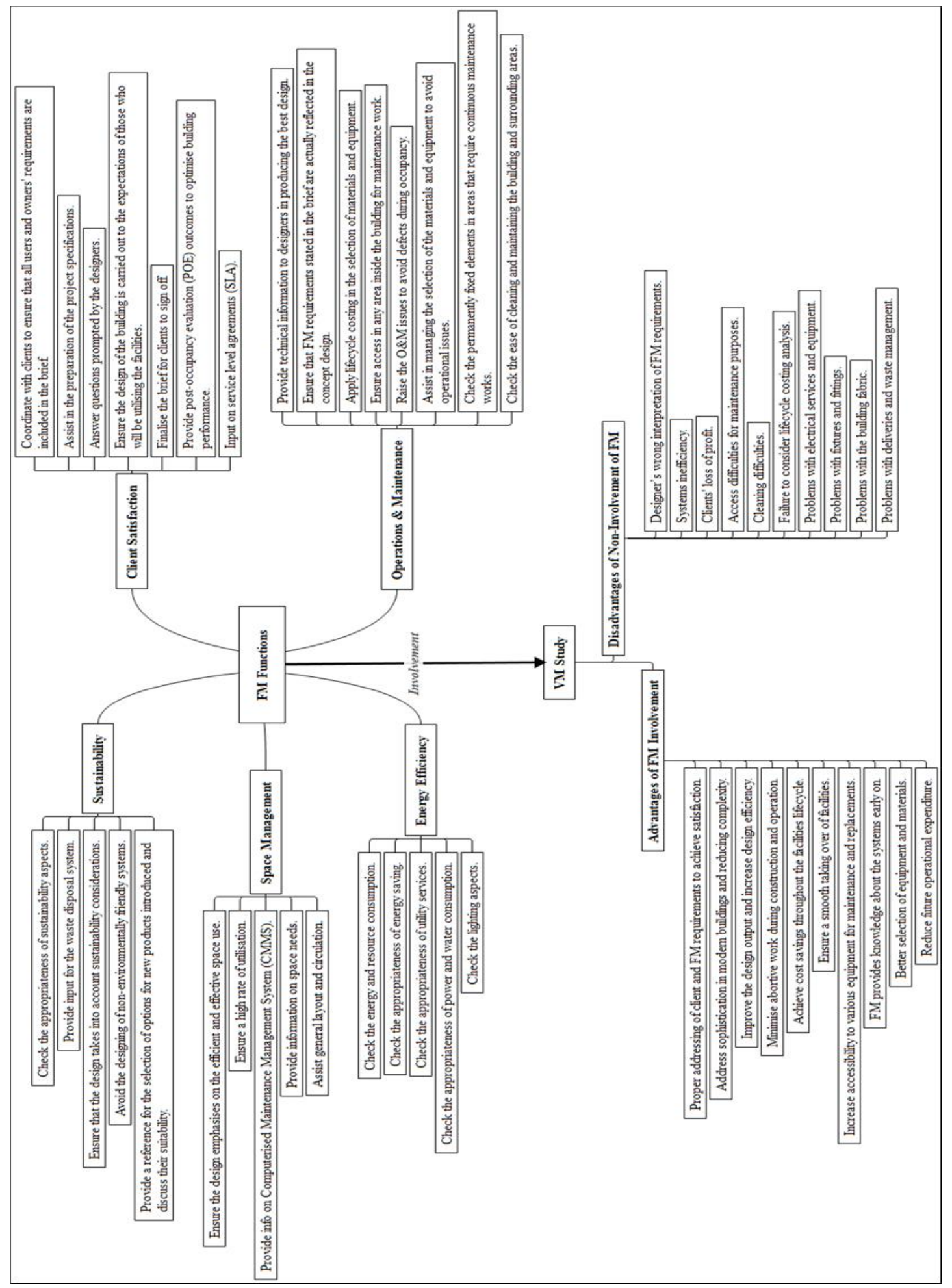

Figure 1- Conceptual Framework 


\section{METHODOLOGY}

\subsection{Preliminary Survey: Semi-Structured Interviews}

A preliminary survey was conducted based on the constructs and items selected from previous research for the purpose of developing the research instrument for the present study. Moreover, the findings from the literature review were utilised in this phase in order to confirm the identified FM functions. Meanwhile, it is important to note that the purpose of conducting the semi-structured interview was to develop an understanding of FM involvements in VM studies. However, this phase does not serve as the main data collection stage because it is only a preliminary phase that explored the FM functions in VM studies prior to rigorous research and comprehensive investigation.

Cavana, Delahaye, and Sekaran (2001) suggested that a qualitative approach such as interview can be adopted to gain familiarity with the phenomena as well as to generate further theories for empirical testing. The key aim of the semi-structured interview is to verify the literature review findings and confirm the functions discovered for the purpose of reflecting the concerns of the participants involved in the industry. More importantly, the process of determining these functions had been imperative and viewed as relevant and critical for VM studies. Furthermore, the semistructured interview sessions allow interviewees to provide their opinions and views on the functions of FM in VM studies.

In the case of the current research, a total of six FM and VM managers with experiences in FM and VM practices were interviewed. Regarding this matter, it should be noted that data saturation is reached when new information is unable to be uncovered by the participants and the information provided by them remain the same during the interview (Glaser \& Strauss, 1967; Bryman, 2012). In this research, no new themes were generated after the fourth interview during the preliminary survey. Therefore, this indicates that the data collection process had reached the saturation point. Furthermore, two additional interviews were conducted to ensure and confirm that no new themes were emerging; hence, the sixth interview successfully confirmed the saturation.

\subsection{Criteria for Selecting The Respondents}

The present study employed purposive sampling in which the interviewees were intentionally selected by the researcher. In this case, it is important to note that the process of selecting participants in a qualitative study depends on whether the individuals are 'information rich' and relevant to the research questions (Bryman, 2012; Creswell, 2014). A number of previous studies (Yasin, 2013; El-Motasem, 2015; Tucker \& Masuri, 2016) suggested that FM and VM managers should be selected as the respondents because they can support the selection of constructs and items for the FM functions. Moreover, the rationale for selecting FM and VM managers in the present study was based on the belief that they can be trusted and considered as reliable respondents due to their familiarity, knowledge, and expertise which fulfils the criteria for FM functions in VM studies. In the case of the present study, the respondents for the semi-structured interview were identified based on the following criteria:

i. Designated at a professional level in the organisation as an FM or VM manager. e.g.; Senior Officer - Grade 44 and above (public sector), Senior manager - (private sector).

ii. Possess extensive knowledge with a working experience of more than five years in FM practice, specifically in performing FM tasks.

iii. Have experience of more than three times than the participants in VM labs, specifically for FM projects.

iv. Currently working in the FM or VM division.

\section{RESULT}

In the semi-structured interview of the present study, a total of seven constructs consisting 50 items were carried forward from the literature review phase to the confirmation phase with the aim of verifying the literature findings as well as confirming the functions discovered from the interviews with FM and VM experts. The semistructured interview session began with questions regarding their brief background (Section A), followed by their opinions on the FM functions in VM studies (Section B). Moreover, it is important to note that each interview was audio-recorded after being 
permitted and acknowledged by interviewees prior to conducting the session.

\subsection{Section A: About The Respondent}

In the case of the current research, each interviewee was assigned with an identification label (A, B, C, D, E, and F) in order to ensure the anonymity and confidentiality of the interviewees' results as shown in Table 2, particularly regarding the background of the interviewees. Apart from that, the interviewees

Table 2: Working Experience of the FM and VM Experts were given the opportunity to propose other relevant FM functions that are applicable in VM studies. The mean score and SD showed (mean $=17.5$ years, $\mathrm{SD}=11.06$ years) in Table 2 conclude that the experts possess vast experience in FM and VM professions and fit the selection criteria of participants.

\begin{tabular}{|l|l|l|l|l|l|l|l|l|}
\hline \multirow{2}{*}{ Questions } & \multicolumn{2}{l|}{ Six expert panels } \\
\cline { 2 - 10 } & $\boldsymbol{A}$ & $\boldsymbol{B}$ & $\boldsymbol{C}$ & $\boldsymbol{D}$ & $\boldsymbol{E}$ & $\boldsymbol{F}$ & Mean & SD \\
\hline $\begin{array}{l}\text { Have you ever been involved in } \\
\text { the VM study? }\end{array}$ & Yes & Yes & Yes & Yes & Yes & Yes & - & - \\
\hline $\begin{array}{l}\text { Does your organisation provide } \\
\text { any Yes } \\
\text { procedures, and/or guidelines } \\
\text { for VM? }\end{array}$ & Yes & Yes & Yes & Yes & Yes & - & - \\
\hline $\begin{array}{l}\text { How many years of experience } \\
\text { do you have in FM? }\end{array}$ & 30 & 8 & 16 & 32 & 13 & 6 & 17.5 & 11.06 \\
\hline
\end{tabular}

\subsection{Section B: About Fm Functions in Vm Studies}

This section provides a detailed discussion on FM functions in VM studies which were confirmed from the preliminary interviews carried out with FM and VM managers who are experienced in VM studies. The interviews managed to validate the findings from the literature review and successfully identified important issues based on the views of the interviewees. In addition, this interview was intended to refine the conceptual framework underpinning the current research by establishing a list of FM functions in VM studies. Therefore, the findings of the current research can be used to further develop the questionnaire survey to the next phase of the study.

Table 3 summarises the content validity analysis results of the interviews as well as the items of FM functions and VM study that managed to be obtained from the preliminary interviews with the expert panels. However, no new items were proposed by the panel. Nevertheless, the findings from this study serve as a stimulus for the next phase of the research.

Table 3: Summary of I-CVI Results

\begin{tabular}{|c|c|c|c|c|}
\hline Latent Construct & Items & Experts Agreement & I-CVI & Decision \\
\hline \multirow{5}{*}{ Client Satisfaction (ClientS) } & ClientS1 & All & 1.00 & Remained \\
\cline { 2 - 5 } & ClientS2 & A,B,D,E,F & 0.83 & Remained \\
\cline { 2 - 5 } & ClientS3 & B,C,D,E,F & 0.83 & Remained \\
\cline { 2 - 5 } & ClientS4 & All & 1.00 & Remained \\
\cline { 2 - 6 } & ClientS5 & B,E,F & 0.50 & Discarded \\
\cline { 2 - 6 } & ClientS6 & All & 1.00 & Remained \\
\cline { 2 - 6 } $\begin{array}{c}\text { Energy Efficiency } \\
\text { (EnerE) }\end{array}$ & ClientS7 & All & 1.00 & Remained \\
\hline & EnerE1 & All & 1.00 & Remained \\
\cline { 2 - 6 } & EnerE2 & All & 1.00 & Remained \\
\cline { 2 - 6 } & EnerE3 & All & 1.00 & Remained \\
\cline { 2 - 6 } & EnerE4 & B,E,F & 0.50 & Discarded \\
\cline { 2 - 6 } & EnerE5 & B,C,E,F & 0.67 & Discarded \\
\hline $\begin{array}{c}\text { Operation and Maintenance } \\
\text { (OpeM) }\end{array}$ & OpeM1 & All & 1.00 & Remained \\
\cline { 2 - 6 } & OpeM2 & C,D,E,F & 0.67 & Discarded \\
\hline
\end{tabular}




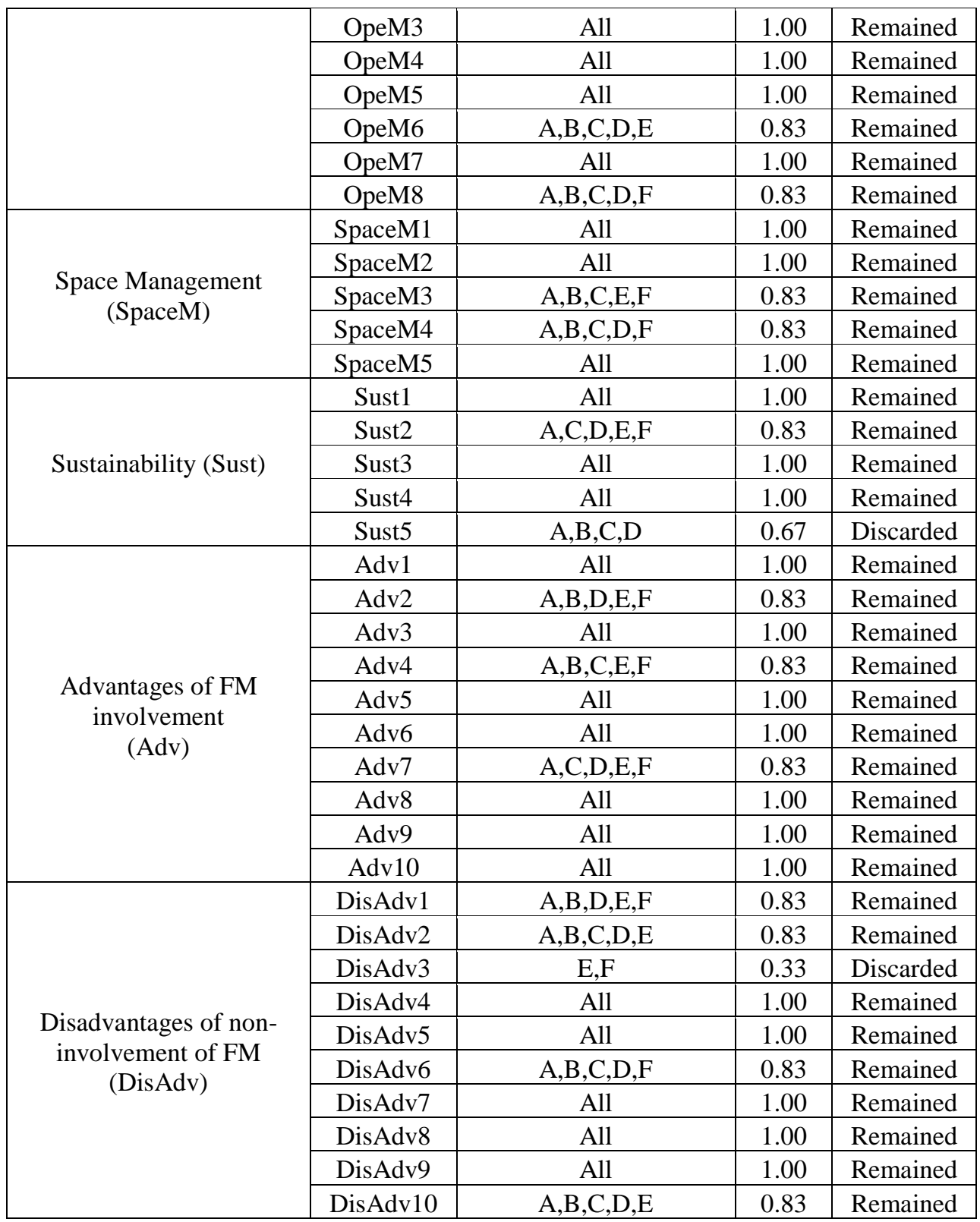

\section{DISCUSSIONS}

Table 2 summarises the characteristics of six FM and VM expert panels who completed the questionnaires. The results showed that all of the respondents were engaged in the VM study based on a minimum of six years and a maximum of 32 years working experience in FM. Hence, this highlights the existence of particular policies and guidelines for VM in their organisation.

According to Polit and Beck (2006), the method of content validity estimation for relevance can be used to calculate the content validity index (ICVI) of individual items. The interviewees were asked to review the relevance of each item based on four answer options ( $1=$ Not relevant, $2=\mathrm{Not}$ important, 3=Relevant, and 4=Very important). In the present study, the cut-off value of I-CVI was set to 0.78 . For instance, the proportion of ICVI would be 0.67 if four experts out of the six experts chose 'relevant' or 'very important', which causes the particular item to be discarded from the measurement items.

The results from this phase of the research act as the verification of the functions identified in the first phase, followed by an in-depth understanding of the functions of FM involvement in VM studies as perceived by the interviewees. The content validity of the research model consisting of 50 items was tested in order to identify the preliminary measures for 
FM functions and VM studies. In this case, the items with I-CVI over 0.78 remained, while the rest were discarded (Aravamudhan \& Krishnaveni, 2016; Hyrkäs, AppelqvistSchmidlechner, \& Oksa, 2003) because the values of more than 0.78 are considered valid (Polit \& Beck, 2006).

Nevertheless, ClientS5 was not validated by interviewee $\mathrm{A}$, interviewee $\mathrm{C}$, and interviewee $\mathrm{D}$ because they claimed that item ClientS5 has a similar meaning as item ClientS1. Hence, this indicates that ClientS5 was an overlapping item, thus it was removed from the construct. Meanwhile, EnerE4 was not approved by interviewee $\mathrm{A}$, interviewee $\mathrm{C}$, and interviewee $\mathrm{D}$ because they claimed that item EnerE4 has the same meaning as item EnerE1. As a result, EnerE4 was considered as an overlapping item which caused it to be removed from the construct. Similarly, item EnerE5 was not validated by interviewee $A$ and interviewee $D$ because it shares the same purpose with the previous item.

Interviewee $\mathrm{A}$ and interviewee $\mathrm{B}$ did not validate OpeM2 because both of them believed that item OpeM2 does not represent operation and maintenance criteria in the construct. Meanwhile, Interviewee $\mathrm{E}$ and interviewee $\mathrm{F}$ did not validate Sust5 because they believed that item Sust5 does not represent the sustainability criteria in the construct. Other than that, DisAdv3 was not agreed by interviewee A, interviewee $\mathrm{B}$, interviewee $\mathrm{C}$, and interviewee $\mathrm{D}$ because it was not suitable to be one of the indicators in the construct.

Overall, it can be clearly concluded that a total of six items did not fit the criteria which caused them to be discarded from the measurement items. According to the summary presented in Table 3, ClientS5 was not validated by Expert A, $\mathrm{C}$, and D, EnerE4 was not approved by expert A, $\mathrm{C}$, and D, EnerE5 was not validated by expert A and D, OpeM2 was not validated by Expert A and B, Sust5 was not validated by Expert E and F, whereas DisAdv3 was only confirmed by Expert $\mathrm{E}$ and $\mathrm{F}$ despite the fact that all of these items were reported in the literature. Therefore, only 44 items under the sub-groups of client's satisfaction, energy efficiency, operation and maintenance, space management, sustainability, and VM study were relevant and best fit the initial development of the integration of FM in VM studies. As a matter of fact, these 44 items were proposed and modified based on the opinions of the experts.

\section{CONCLUSION}

Overall, the present study concluded that VM ought to be connected with all of the project stages. However, an earlier start is always a great decision to minimise the obliged investments in executing any adjustments as well as the need to save money, efforts, and achieve the best quality and ideal solution for emerging issues. Moreover, it should be noted that the main goal of an FM manager is to ensure the functionality of the built environment by taking into consideration the aspects of people, place, process, and technology. Therefore, it should be applied throughout the whole life cycle of the building starting from the pre-construction phase with the aim of achieving optimum results, avoiding unnecessary problems as well as a means of saving time, effort, and money.

On another note, the findings of the qualitative data can be used to confirm the functions needed in ensuring that FM managers are regularly involved in VM studies. More importantly, this data will become the basis for future research to proceed with a quantitative strategy, particularly in establishing an FM-VM integration framework. In other words, the findings from this preliminary phase of research can be employed to assist further development of the questionnaire survey which includes summarising the profiles of individual interview participants as well as interpreting the meaning of the discussion. On a final note, it should be understood that the purpose of individual interviews is to qualitatively confirm the issues that are grounded in the theory obtained from the intensive literature review.

\section{ACKNOWLEDGEMENTS}

The current research benefited from a grant provided by the University of Malaya under FRGS Project No. FP025-2014B. The authors would like to express their deepest gratitude towards the anonymous referees for their help and constructive comments.

\section{REFERENCES}

1 Abdullah, S. A., Sulaiman, N., Latiffi, A. A., \& Baldry, D. (2014). Building information modelling (BIM) from the perspective of facilities management (FM) in Malaysia. In International Real Estate Symposium 2014 (IRERS) (pp. 1-16).

2 Ahzahar, N., Karim, N. A., Hassan, S. H., \& Eman, J. (2011). A study of contribution 
factors to building failures and defects in construction industry. 2nd International Building Control Conference, 20, 249-255.

3 Al-Hammad, A., Assaf, S., \& Al-Shihah, M. (1997). The effect of faulty design on building maintenance. Journal of Quality in Maintenance Engineering, 3(1), 29-39.

4 Alriwaimi, H. M. R., \& Akasah, Z. A. B. (2014). Faulty factors in building maintenance during design stage. In Recent Trends in Social and Behaviour Sciences Proceedings of the 2nd International Congress on Interdisciplinary Behavior and Social Sciences 2013, ICIBSoS 2013 (pp. 443-448). Taylor and Francis - Balkema. Retrieved from http://www.scopus.com/inward/record.url?ei $\mathrm{d}=2$ s2.084894875675\&partnerID=tZOtx3y1

5 Andersen, M. (2006). Four uses of service level agreements. In $C I B \quad W 70$ Facilities Management Symposium (pp. 401-407). Trondheim.

6 Ann, Y. T. W. (2006). A value management framework for systematic identification and precise representation of client requirements in the briefing process. (Doctoral dissertation). Hong Kong Polytechnic University.

7 Aravamudhan, N. R., \& Krishnaveni, R. (2016). Establishing content validity for new performance management capacity building scale. IUP Journal of Management Research, $X V(3), \quad 2016 . \quad$ Retrieved from http://www.iupindia.in/

8 Arditi, D., \& Nawakorawit, M. (1999). Designing buildings for maintenance: Designers' perspective. Journal of Architectural Engineering, 5(4), 107-116. https://doi.org/10.1061/(ASCE)10760431(1999)5:4(107)

9 Aris, R. (2006). Maintenance factors in building design. (Master's thesis). Universiti Teknologi Malaysia.

10 Atkin, B., \& Björk, B. (2007). Understanding the context for best practice facilities management from the client's perspective. Facilities, 25(13/14), 479-492. https://doi.org/10.1108/02632770710822580

11 Bascoul, A. M. (2017). Managing project structural complexity by integrating facility management in planning, designing, and execution of high-end facility upgrades. (Doctoral dissertation). University of California. Retrieved from https://escholarship.org/uc/item/5xw9d58v

12 Becerik-Gerber, B., Jazizadeh, F., Li, N., \& Calis, G. (2012). Application areas and data requirements for BIM - Enabled facilities management. Journal of Construction Engineering and Management, 138(3), 431442.

https://doi.org/10.1061/(ASCE)CO.19437862.0000433

13 Bosch, S. J., \& Pearce, A. R. (2003). Sustainability in public facilities: Analysis of guidance documents. Journal of Performance of Constructed Facilities, 17(1), 9-18. https://doi.org/10.1061/(ASCE)08873828(2003)17:1(9)

14 Bryman, A. (2012). Social research methods (4th ed.). Oxford: Oxford University Press.

15 Cao, Y., Song, X., \& Wang, T. (2015). Development of an energy-aware intelligent facility management system for campus facilities. Procedia Engineering, 118, 449456.

https://doi.org/10.1016/j.proeng.2015.08.44 6

16 Cavana, R. Y., Delahaye, B. L., \& Sekaran, U. (2001). Applied business research: Qualitative and quantitative methods (Australian). Milton, Qld.: John Wiley \& Sons.

17 Chan, E. (2014). Building maintenance strategy: A sustainable refurbishment perspective. Universal Journal of Management, 2(1), 19-25. https://doi.org/10.13189/ujm.2014.020103

18 Che Mat, M. M., \& Shah, Z. M. (2006). Value management as an effective and efficient tool for space management. Retrieved from http://www.vmacademy.com/seminar_paper_01.pdf

19 Chotipanich, S. (2004). Positioning facility management. Facilities, 22(13/14), 364-372. https://doi.org/10.1108/02632770410563086

20 CIBSE. (2000). Guide to ownership, operation and maintenance of building services. London, UK: The Chartered 
Institute of Building Service Engineers.

21 Cipriano, X., Carbonell, J., \& Cipriano, J. (2009). Monitoring and modelling energy efficiency of municipal public buildings: Case study in Catalonia region. International Journal of Sustainable Energy, 28(1-3), 318.

https://doi.org/10.1080/14786450802452332

22 Coenen, C., \& Schäfer-Cui, Y. Y. (2013). Relationship value in FM: A customer perspective. In EFMC2013, Presentation (pp. 1-18). Prague.

23 Creswell, J. W. (2014). Educational research: Planning, conducting, and evaluating quantitative and qualitative research (4th ed.). Harlow, Essex: Pearson Education Limited.

24 Dakwale, V. A., Ralegaonkar, R. V., \& Mandavgane, S. (2011). Improving environmental performance of building through increased energy efficiency: A review. Sustainable Cities and Society, 1(4), 211-218.

https://doi.org/10.1016/j.scs.2011.07.007

25 De Silva, N. (2011). Promoting the facilities management profession in the project development phase of high-rise buildings in Sri Lanka. Built Environment Sri Lanka, 910(1-2), 37-44. https://doi.org/10.4038/besl.v9i1-2.3063

26 El-Motasem, S. M. (2015). Integrating value engineering and facility management as an approach to face risks. (Master's thesis). Ain-Shams University, Cairo, Egypt. Retrieved from http://www.cpasegypt.com/pdf/Samar_ElMotasem/Samar_El Motasem_Thesis.pdf

27 Eley, J. (2001). How do post-occupancy evaluation and the facilities manager meet? Building Research and Information, 29(2), 164-167. Retrieved from http://explore.bl.uk/primo_library/libweb/act ion/display.do?tabs=detailsTab\&gathStatTa $\mathrm{b}=$ true $\& \mathrm{ct}=$ display $\& \mathrm{fn}=$ search $\&$ doc $=$ ETOC RN105726211\&ind $=1 \&$ recIds $=$ ETOCRN 1 05726211

28 Elmualim, A., Shockley, D., Valle, R., Ludlow, G., \& Shah, S. (2010). Barriers and commitment of facilities management profession to the sustainability agenda. Building and Environment, 45(1), 58-64. https://doi.org/10.1016/j.buildenv.2009.05.0 02

29 Elmualim, A., Valle, R., \& Kwawu, W. (2012). Discerning policy and drivers for sustainable facilities management practice. International Journal of Sustainable Built Environment, $\quad 1(1), \quad 16-25$. https://doi.org/10.1016/j.ijsbe.2012.03.001

30 Enoma, A. (2005). The role of facilities management at the design stage. In Annual Conference - ARCOM (Vol. 1, pp. 421-430). London, England: Association of Researchers in Construction Management.

31 Feciková, I. (2004). An index method for measurement of customer satisfaction. The TQM Magazine, 16(1), 57-66. https://doi.org/10.1108/09544780410511498

32 Femi, O. T. (2014). Effects of faulty design and construction on building maintenance. International Journal of Technology Enhancements and Emerging Engineering Research, 2(5), 59-64.

33 Fraser, K. (2014). Facilities management: The strategic selection of a maintenance system. Journal of Facilities Management, 12(1), 18-37. https://doi.org/10.1108/JFM02-2013-0010

34 Friege, J., \& Chappin, E. (2014). Modelling decisions on energy- efficient renovations: A review. Renewable and Sustainable Energy Reviews, 39, 196-208. https://doi.org/10.1016/j.rser.2014.07.091

35 Geethanjali, B., Hansa, L. M., \& Daniel, M. (2007). An optimization of effective energy management as a tool to facilitate managers. In WIT Transactions on Ecology and the Environment (Vol. 105, pp. 61-72). Southampton. Retrieved from http://explore.bl.uk/primo_library/libweb/act ion/display.do?tabs=detailsTab\&gathStatTa $\mathrm{b}=$ true \&ct $=$ display $\& \mathrm{fn}=$ search $\&$ doc $=E T O C$ CN064695883\&ind $x=1 \&$ recIds $=$ ETOCCN0 64695883

36 Glaser, B. G., \& Strauss, A. L. (1967). The discovery of grounded theory: Strategies for qualitative research. London: Weidenfeld and Nicolson. Retrieved from http://www.sxf.uevora.pt/wpcontent/uploads/2013/03/Glaser_1967.pdf

37 Goulden, M., \& Spence, A. (2015). Caught in 
the middle: The role of the facilities manager in organisational energy use. Energy Policy, 85 , 280-287. https://doi.org/10.1016/j.enpol.2015.06.014

38 Hajek, P. (2002). Sustainable construction through environmentally based optimisation. In IABSE Reports (pp. 190-191). Melbourne, Australia. Retrieved from http://explore.bl.uk/primo_library/libweb/act ion/display.do?tabs=detailsTab\&gathStatTa $\mathrm{b}=$ true \&ct $=$ display $\& \mathrm{fn}=$ search $\&$ doc $=$ ETOC CN046630543\&ind $=1 \&$ recIds $=$ ETOCCN0 46630543

39 Hartungi, R., \& Jiang, L. (2012). Energy efficiency and conservation in an office building: A case study. International Journal of Energy Sector Management, 6(2), 175188.

https://doi.org/10.1108/17506221211242059

40 Hassanain, M. A., Al-Hammad, A. M., \& Fatayer, F. (2014). Assessment of architectural defects attributed to lack of maintenance feedback to the design team. Architectural Science Review, 57(2), 132138.

https://doi.org/10.1080/00038628.2013.7834 59

41 Hayles, C., Graham, M., \& Fong, P. S. W. (2010). Value management for sustainable decision making. In Proceedings - Institution of Civil Engineers Municipal Engineer (Vol. 163, pp. 43-50). Great Britain: Thomas Telford Services Ltd. https://doi.org/10.1680/muen.2010.163.1.43

42 Hodges, C. P. (2005). A facility manager's approach to sustainability. Journal of Facilities Management, 3(4), 312-324. https://doi.org/10.1108/14725960510630498

43 Hui, E. C. M., Zhang, P., \& Zheng, X. (2013). Facilities management service and customer satisfaction in shopping mall sector. Facilities, 31(5/6), 194-207. https://doi.org/10.1108/02632771311307070

44 Hungu, C. F. (2013). Utilization of BIM from early design stage to facilitate efficient FM operations. (Master's thesis). Chalmers University of Technology, Göteborg, Sweden.

45 Hyrkäs, K., Appelqvist-Schmidlechner, K., \& Oksa, L. (2003). Validating an instrument for clinical supervision using an expert panel.
International Journal of Nursing Studies, 40(6), 619-625. https://doi.org/10.1016/S00207489(03)00036-1

46 Ibiyemi, A., Adnan, Y. M., Daud, M. N., \& Adenipekun, M. (2014). An examination of the structure of sustainable facilities planning scale for user satisfaction in Nigerian universities. Australasian Journal of Construction Economics and Building, 14(3), 58-73.

https://doi.org/10.5130/ajceb.v14i3.4157

47 Ibrahim, I., Yusoff, W. Z. W., \& Sidi, N. S. S. (2011). A comparative study on elements of space management in facilities management at higher education institutions. In International Conference on Sociality and Economics Development (Vol. 10, pp. 7478). Singapore: IACSIT. Retrieved from https://www.researchgate.net/publication/25 8884866_A_Comparative_Study_on_Eleme nts_of_Space_Management_in_Facilities_M anagement_at_Higher_Learning_Institutions

48 IFMA. (2014). Sustainability. Retrieved from

http://community.ifma.org/fmpedia/w/fmpe dia/sustainability

49 Ikediashi, D. I. (2014). A framework for outsourcing facilities management services in Nigeria's public hospitals. (Doctoral dissertation). Heriot-Watt University, Edinburgh, United Kingdom.

50 Ilesanmi, A. O. (2010). Post-occupancy evaluation and residents' satisfaction with public housing in Lagos, Nigeria. Journal of Building Appraisal, 6(2), 153-169. https://doi.org/10.1057/jba.2010.20

51 Isa, N. M., Kamaruzzaman, S. N., Mohamed, O., \& Berawi, M. A. (2017). Review of facilities management functions in value management practices. International Journal of Technology, 8(5), 830-840. https://doi.org/10.14716/ijtech.v8i5.865

52 Ishak, N. H., Ramly, A., \& Chohan, A. H. (2007). Implications of design deficiency on building maintenance at post-occupational stage. Journal of Building Appraisal, 3(2), 115-124. https://doi.org/10.1057/palgrave.jba.295006

53 Islam, R., Mohamad, S. F., Bjørberg, S., 
Misnan, M. S., \& Yusof, Z. M. (2017). Towards a framework to integrate facilities management cost effective parameters in design process. International Journal of Engineering and Technology, 9(6), 45154526.

https://doi.org/10.21817/ijet/2017/v9i6/1709 06063

54 Jackson, L. (2018). What is Space Management. Retrieved from https://fmsystems.com/blog/what-is-spacemanagement/

55 Jaunzens, D., Warriner, D., Garner, U., \& Waterman, A. (2001). Applying facilities expertise in building design. Bracknell, United Kingdom: Ihs Bre Press.

56 Jawdeh, H. B. (2013). Improving the integration of building design and facilities management. (Doctoral dissertation). University of Salford, Salford, UK.

57 Jawdeh, H. B., Wood, G., \& Abdul-Malak, M. A. (2010). Altering design decisions to better suit facilities management processes. In Tenth International Conference for Enhanced Building Operations (pp. 1-7). Kuwait: 10th International Conference for Enhanced Building Operations. Retrieved from http://hdl.handle.net/1969.1/94095

58 Jensen, P. A. (2009). Design integration of facilities management: A challenge of knowledge transfer. Architectural, Engineering and Design Management, 5(3), 124-135.

https://doi.org/10.3763/aedm.2009.0101

59 Jensen, P. A., Van der Voordt, T. J., Coenen, C., \& Sarasoja, A.-L. (2014). Reflecting on future research concerning the added value of FM. Facilities, 32(13/14), 856-870. https://doi.org/10.1108/F-09-2012-0070

60 Kalantari, S., Shepley, M. M., Rybkowski, Z. K., \& Bryant, J. (2017). Designing for operational efficiency: Facility managers' perspectives on how their knowledge can be better incorporated during design. Architectural Engineering and Design Management, 13(6), 457-478. https://doi.org/10.1080/17452007.2017.1348 333

61 Karunasena, G., Rathnayake, R. M. N. U., \& Senarathne, D. (2016). Integrating sustainability concepts and value planning for sustainable construction. Built Environment Project and Asset Management, 6(2), $125-138$. https://doi.org/10.1108/BEPAM-09-20140047

62 Koleoso, H., Omirin, M., Adewunmi, Y., \& Babawale, G. (2013). Applicability of existing performance evaluation tools and concepts to the Nigerian facilities management practice. International Journal of Strategic Property Management, 17(4), 361-376. https://doi.org/10.3846/1648715X.2013.861 367

63 Korpela, J., Miettinen, R., Salmikivi, T., \& Ihalainen, J. (2015). The challenges and potentials of utilizing building information modelling in facility management: The case of the Center for Properties and Facilities of the University of Helsinki. Construction Management and Economics, 33(1), 3-17. https://doi.org/10.1080/01446193.2015.1016 540

64 Lavy, S. (2008). Facility management practices in higher education buildings: A case study. Journal of Facilities Management, 6(4), 303-315. https://doi.org/10.1108/14725960810908163

65 Lee, S. Y., \& Kang, M. (2013). Innovation characteristics and intention to adopt sustainable facilities management practices. Ergonomics, 56(3), 480-491. https://doi.org/10.1080/00140139.2012.7521 10

66 Lepkova, N., \& Jefimoviene, G. Z. (2012). Study on customer satisfaction with facilities management services in Lithuania. Slovak Journal of Civil Engineering, 20(4), 1-16. https://doi.org/10.2478/v10189-012-0017-4

67 Lepkova, N., \& Uselis, R. (2013). Development of a quality criteria system for facilities management services in Lithuania. Procedia Engineering, 57, 697-706. https://doi.org/10.1016/j.proeng.2013.04.08 8

68 Liang, J., Li, B., Wu, Y., \& Yao, R. (2007). An investigation of the existing situation and trends in building energy efficiency management in China. Energy and Buildings, 39(10), 1098-1106. https://doi.org/10.1016/j.enbuild.2006.12.00 2 
69 Mcauley, B., Hore, A., West, R. P., \& Horan, T. (2015). The development of key performance indicators to monitor early facilities management performance through the use of BIM technologies in public sector projects. In Proceedings of the 2nd Proceedings International Conference on Civil and Building Engineering Informatics (pp. 1-8). Tokyo, Japan. Retrieved from https://arrow.dit.ie/cgi/viewcontent.cgi?artic $\mathrm{le}=1096 \&$ context $=$ beschreccon

70 Meng, X. (2013). Involvement of facilities management specialists in building design: United Kingdom experience. Journal of Performance of Constructed Facilities, 27(5), 500-507. https://doi.org/10.1061/(ASCE)CF.19435509.0000343

71 Mustapa, M. (2013). Facilities management knowledge in private finance initiative (PFI) healthcare projects. (Doctoral dissertation). Loughborough University. Retrieved from https://dspace.lboro.ac.uk/dspacejspui/bitstream/2134/12843/4/Thesis-2013Mustapa.pdf

72 Nawi, M. N. M., Radzuan, K., Salleh, N. A., \& Ibrahim, S. H. (2014). Value management: A strategic approach for reducing faulty design and maintainability issue in IBS building. Advances in Environmental Biology, 8(5), 1859-1863.

$73 \mathrm{Ng}$, B. H. (2013). Development of energyefficient building environmental quality evaluation framework. (Master's thesis). Universiti Tun Hussein Onn, Malaysia.

74 Nielsen, S. B., Sarasoja, A.-L., \& Galamba, K. R. (2016). Sustainability in facilities management: An overview of current research. Facilities, 34(9/10), 535-563. https://doi.org/10.1108/F-07-2014-0060

75 Noor, M. N. M., \& Pitt, M. (2009). A critical review on innovation in facilities management service delivery. Facilities, $27(5 / 6)$, 211-228 https://doi.org/10.1108/02632770910944943

76 Noor, N. A. M. (2014). Framework of whole life cycle costing for Malaysian high rise residential property development. (Doctoral dissertation). Queensland University of Technology.
77 Oke, A. E., \& Aigbavboa, C. O. (2017). The concept of value management. In Sustainable value management for construction projects (pp. 1-195). Cham, Switzerland: Springer International https://doi.org/10.1007/978-3-319-541518_2

78 Pilanawithana, N. M. Sandanayake, Y. G. (2017). Positioning the facilities manager's role throughout the building lifecycle. Journal of Facilities Management, 15(4), 376-392. https://doi.org/10.1108/JFM-062016-0024

79 Pitt, M. (2005). Trends in shopping centre waste management. Facilities, 23(11/12), 522-533. https://doi.org/10.1108/02632770510618480

80 Polit, D. F., \& Beck, C. T. (2006). The content validity index: Are you sure you know what's being reported? Critique and recommendations. Research in Nursing \& Health, 29, 489-497. https://doi.org/10.1002/nur.20147

81 Poór, P., Kuchtová, N., \& Šimon, M. (2014). Machinery maintenance as part of facility management. Procedia Engineering, 69, 1276-1280. https://doi.org/10.1016/j.proeng.2014.03.11 9

82 Potkany, M., Vetrakova, M., \& Babiakova, M. (2015). Facility management and its importance in the analysis of building life cycle. Procedia Economics and Finance, 26(15), 202-208. https://doi.org/10.1016/S22125671(15)00814-X

83 Preiser, W. F. E. (1995). Post-occupancy evaluation: How to make buildings work better. Facilities, 13(11), 19-28. https://doi.org/10.1108/02632779510097787

84 Preiser, W. F. E. (2003). Continuous quality improvement through post-occupancy evaluation feedback. Journal of Corporate Real Estate, 5(1), 42-56. https://doi.org/10.1108/14630010310811993

85 Price, S. (2012). To deliver a sustainable built estate; The management and operationalisation of sustainable facilities management. (Doctoral dissertation). University College London. 
86 Price, S., Pitt, M., \& Tucker, M. (2011). Implications of a sustainability policy for facilities management organisations. Facilities, 29(9/10), 391-410. https://doi.org/10.1108/02632771111146314

87 PWD. (2017). Garis panduan mewujudkan dan melaksanakan sistem pengurusan tenaga bagi bangunan-bangunan kerajaan (2nd ed., Vol. JKR20500-0). Malaysia: Public Work Department.

88 Qian, Q. K., \& Chan, E. H. W. (2010). Government measures needed to promote building energy efficiency (BEE) in China. Facilities, 28(11/12), 564-589. https://doi.org/10.1108/02632771011066602

89 Rahman, S. A., \& Salim, N. A. A. (2013). A study on design defects affecting maintenance. In The 5th Undergraduate Maintenance and Facilities Maintenance Conference (pp. 1-7). Malaysia. Retrieved from

https://www.academia.edu/5525497/A_STU DY_ON_DESIGN_DEFECTS_AFFECTIN G_MAINTENANCE

90 Ransley, J., \& Ingram, H. (2001). What is 'good' hotel design? Facilities, 19(1/2), 7987.

https://doi.org/10.1108/02632770110362857

91 Razak, M. A., \& Jaafar, M. (2012). An assessment on faulty public hospital design in Malaysia. Journal Design + Built, 5(1), 114. Retrieved from http://spaj.ukm.my/jsb/index.php/jdb/article/ viewFile/27/19

92 Saleh, A. A., Kamarulzaman, N., Hashim, H., \& Hashim, S. Z. (2011). An approach to facilities management (FM) practices in higher learning institutions to attain a sustainable campus (Case Study: University Technology Mara - UiTM). Procedia Engineering, 20, 269-278. https://doi.org/10.1016/j.proeng.2011.11.16 5

93 Sapp, D. (2017). Facilities operations and maintenance - An overview. Retrieved from https://www.wbdg.org/facilities-operationsmaintenance

94 Savanick, S., Strong, R., \& Manning, C. (2008). Explicitly linking pedagogy and facilities to campus sustainability: Lessons from Carleton College and the University of Minnesota. Environmental Education
Research, 14(6), 667-679. https://doi.org/10.1080/13504620802469212

95 Shafie, F., Yusoff, W. Z. W., \& Pawi, S. (2012). Users' satisfaction towards facilities management, FM help desk in public higher educational institutions in Malaysia. Advances in Management \& Applied Economics, 2(3), 59-69. Retrieved from http://www.scienpress.com/Upload/AMAE $\% 2 \mathrm{FVol} 2 \_3$ 5.pdf

96 Sheau, T. L., Mohammed, A. H., Weng, W. C., \& Alias, B. (2010). Facilities management: Paths of Malaysia to achieve energy sustainability. International Journal of Facility Management, 1(2), 1-10. Retrieved from https://www.researchgate.net/publication/25 8520953_Facilities_management_paths_of_ Malaysia_to_achieve_energy_sustainability

97 Shen, W., Hao, Q., \& Xue, Y. (2012). A loosely coupled system integration approach for decision support in facility management and maintenance. Automation in Construction, 25, 41-48. https://doi.org/10.1016/j.autcon.2012.04.003

98 Suffian, A. (2013). Some common maintenance problems and building defects: Our experiences. Procedia Engineering, 54, 101-108. https://doi.org/10.1016/j.proeng.2013.03.00 9

99 Suhaimi, M. S. (2014). Value management in design planning: A systems-based framework for multi-disciplinary team involvement. (Doctoral dissertation). Queensland University of Technology.

100 Tahir, M. Z., Nawi, M. N. M., \& Ibrahim, A. (2016). Value management (VM): A strategic approach for improving energy efficiency. International Journal of Supply Chain Management, 5(4), 201-208. Retrieved from https://www.researchgate.net/publication/31 3366899_Value_Management_VM_A_Strat egic_Approach_for_Improving_Energy_Effi ciency

101 Tahir, M. Z., Nawi, M. N. M., \& Rajemi, M. F. (2016). The potential of value management (VM) to improve the consideration of energy efficiency within pre-construction. In International Conference on Applied Science and 
Technology 2016 (Vol. 1761, pp. 020102-1020102-020106). AIP Publishing. https://doi.org/10.1063/1.4960942

102 Tladi, K. (2012). Evaluating the facility manager's role in project design. (Master's thesis). University of the Witwatersrand, Johannesburg.

103 Toor, S. U. R., \& Ogunlana, S. O. (2010). Beyond the 'iron triangle': Stakeholder perception of key performance indicators (KPIs) for large-scale public sector development projects. International Journal of Project Management, 28(3), 228-236. https://doi.org/10.1016/j.ijproman.2009.05.0 05

104 Treloar, G. J., McCoubrie, A., Love, P. E. D., \& Iyer-Raniga, U. (1999). Embodied energy analysis of fixtures, fittings and furniture in office buildings. Facilities, 17(11), 403-410. https://doi.org/10.1108/02632779910291877

105 Tucker, M., \& Masuri, M. R. A. (2016). The rationale to integrate facilities management into the development process. Property Management, 34(4), 332-344. https://doi.org/10.1108/PM-08-2015-0040

106 Von Felten, D., Coenen, C., \& Moos, I. A. (2009). FM dashboard: A facility management monitoring tool for planning, design and construction to optimize function and cost in operations. Journal of Corporate Real Estate, 11(2), 115-127. https://doi.org/10.1108/14630010910963151

107 Wan-Hamdan, W. S. Z., Hamid, M. Y., \& Mohd-Radzuan, N. a. (2011). Contribution of Facilities Management Processes in Supporting Malaysia National Higher Education Strategic Plan. Procedia Engineering, 20, 180-187. Retrieved from http://linkinghub.elsevier.com/retrieve/pii/S 1877705811029638

108 Wang, Y., Wang, X., Wang, J., Yung, P., \&
Jun, G. (2013). Engagement of facilities management in design stage through BIM: Framework and a case study. Advances in Civil Engineering, 2013, 1-8. https://doi.org/10.1155/2013/189105

109 Way, M. (2006). Soft landings: A fresh scope of service that ensures users and clients get the best out of a new building. Journal of Facilities Management, 4(1), 23-39. https://doi.org/10.1108/14725960610644203

110 Wood, H. L. (2010). Modelling project complexity at the pre construction stage. (Doctoral dissertation). University of Brighton.

111 Wright, T. S. A., \& Wilton, H. (2012). Facilities management directors' conceptualizations of sustainability in higher education. Journal of Cleaner Production, $31,118-125$.

https://doi.org/10.1016/j.jclepro.2012.02.030

112 Xu, P. P., Chan, E. H. W., \& Qian, Q. K. (2011). Key performance indicators (KPI) for the sustainability of building energy efficiency retrofit (BEER) in hotel buildings in China. Facilities, 30(9/10), 432-448. https://doi.org/10.1108/02632771211235242

113 Yasin, M. F. M. (2013). The contributions of knowledge mapping in facilities performance evaluation practice in Malaysia. (Doctoral dissertation). University of Salford, Salford, UK.

114 Zakaria, H., Arifin, K., Ahmad, S., Aiyub, K., \& Fisal, Z. (2011). Pengurusan fasiliti dalam penyelenggaraan bangunan: Amalan kualiti, keselamatan dan kesihatan. TechnoSocial, 2(1), 23-36. Retrieved from http://eprints.uthm.edu.my/579/1/jtsv22010p 3.pdf

115 Zhang, K. (1999). Life cycle costing for office buildings in Canada. (Master's thesis). Concordia University, Montreal, Quebec, Canada. 